\title{
Learning from Home Strategies in Private Elementary Schools During Covid-19 Pandemic
}

\section{Dyah Worowirastri Ekowati ${ }^{*}$, Beti istanti Suwandayani ${ }^{2}$}

\author{
1,2 Program Studi Pendidikan Guru Sekolah Dasar, Universitas Muhammadiyah Malang, Malang, Indonesia
}

\section{ART I C L E I N F O}

Article history:

Received April 05, 2021

Revised April 10, 2021

Accepted July 10, 2021

Available online August 25, 2021

Kata Kunci:

Strategi Belajar Dari Rumah, SD Swasta

Keywords:

Learning From Home Strategy, Private Elementary School

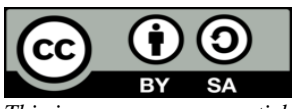

This is an open access article under the CC BY-SA license.

Copyright (C) 2021 by Author. Published by Universitas Pendidikan Ganesha.

\section{A B S T R A C T}

\section{A B S T R A K}

Pemerintah Indonesia menetapkan kebijakan Belajar Dari Rumah (BDR) terkait pembelajaran di masa pandemi Covid-19. Penelitian ini bertujuan untuk menganalisis strategi belajar dari rumah selama pandemi covid-19 di SD swasta Indonesia. Metode penelitian dilakukan secara deskriptif kualitatif. Pengumpulan data melalui wawancara, observasi, dan dokumentasi. Analisis data dalam penelitian kualitatif ini dimulai pada saat pengumpulan data berlangsung, dan setelah pengumpulan data selesai dalam jangka waktu tertentu. Analisis data menggunakan teknik analisis isi. Kegiatan dalam analisis data meliputi reduksi data yang merangkum, memilih pokokpokok pokok, memfokuskan pada hal-hal yang penting, serta mencari tema dan pola. Selain itu, tampilan data mengorganisasikan data, disusun dalam pola hubungan, sehingga lebih mudah dipahami. Subjek penelitian yaitu Kepala Sekolah (key informant), Guru, siswa, 2 wali murid. Hasil analisis menunjukkan bahwa BDR dilakukan dengan blended learning (sinkronous dan asinkronous). Pelaksanaan sinkronous menggunakan media sosial (WA, IG, Zoom, Google meet) dan aplikasi pembelajaran sekolah yang durasinya dilakukan selama 1-3 jam. Sedangkan asinkronous dilakukan dengan pengiriman tugas/proyek/soal melalui media sosial atau aplikasi PANDHAWA setiap hari atau seminggu sekali. Perbedaan strategi sesuai dengan kesiapan sekolah, sarana prasarana, SDM Guru, siswa serta orang tua. Dengan berbagai strategi BDR yang diterapkan, sekolah dapat mengatasi kekurangan dan meningkatkan serta mengembangkan kualitas pembelajaran.

\begin{abstract}
The Indonesian government established a Learning from Home (BDR) policy related to learning during the Covid-19 pandemic. This article aims to analysis learning strategies from home during the Covid-19 pandemic in Indonesian private elementary schools. The research method was carried out in a descriptive qualitative manner. Collecting data through interviews, observation, and documentation. Data analysis in this qualitative research was started when the data collection took place, and after the data collection was completed within a certain period. The data analysis implemented content analysis techniques. Activities in data analysis included data reduction which summarized, chose the main points, focused on the important things, as well as looking for themes and patterns. Moreover, data display organized the data, arranged in a relationship pattern, so that it would be more easily understood. The research subjects were the principal (key informant), teacher, students, 2 guardians. The results of the analysis show that BDR is carried out using blended learning (synchronous and asynchronous). Synchronous implementation using social media (WA, IG, Zoom, Google meet) and school learning applications with a duration of 1-3 hours. Meanwhile, asynchronous is done by sending assignments/projects/questions via social media or the PANDHAWA application every day or once a week. Different strategies are following the readiness of schools, infrastructure, human resources, teachers, students, and parents. With various BDR strategies implemented, schools can overcome deficiencies and improve and develop the quality of learning.
\end{abstract}

\section{INTRODUCTION}

COVID-19, known as 2019-nCoV, is a new corona virus disease that became known at the end of December 2019 in Wuhan, China (Masonbrink \& Hurley, 2020). The corona virus is a large virus family that usually attacks the respiratory tract organs (Spinelli \& Pellino, 2020). This name comes from the Latin word "Corona", meaning crown, because of the sharp edges that surround this virus (Chowell \& Mizumoto, 2020). These viruses act more like highly contagious ones such as influenza (Bostan et al., 2020) more quickly than scientists found in their slow-moving viral relatives, SARS and MERSS (Alrefaie et al., 2020). The current condition is a very critical public health problem, and requires proactive action to protect the public (Phelps \& Sperry, 2020). This is based on data as of May 17, 2021 on the official covid-19 website https://covid19.go.id/, as many as 3.375 .573 people died out of 162.773 .940 confirmed cases. This situation, along with its spread in 223 nations, is expected to continue mining. Indonesia recorded 48.305 deaths from 1.744 .045 confirmed cases. The effect caused by this virus is so great. The 
handling of this virus affects a variety of fields, including the field of education (Chowell \& Mizumoto, 2020; Masonbrink \& Hurley, 2020). So that appropriate efforts are needed so that learning can take place during the COVID-19 pandemic. In order to prevent the transmission of Covid-19, the Ministry of Education and Culture issued three circular letters related to the prevention and treatment of Covid-19. Regarding the instructions regarding the learning process from home, each school has different strategies to make it happen, both public and private schools. This is related to learning from home involving teachers and students through Distance Learning (Arifa, 2020; Kurniasari et al., 2020). In addition, it also involves school readiness, infrastructure, human resources for teachers, students and parents. One of the strategies used is online learning or learning from home. It is called BDR.

The BDR provisions are as follows: a. Home learning through online learning is implemented to provide meaningful learning experiences for students. It is also intended to reduce the burden on students on the demands of completing all curriculum achievements for the requirements for class promotion and graduation; b. Learning from home can focus on life skills education related to the Covid-19 pandemic; c. Home Learning activities and assignments may differ between students, according to their interests and conditions, taking into account gaps in access/learning facilities at home; d. Indications or products of Learning from Home activities are given qualitatively and useful feedback from the teacher, without having to provide quantitative values (Kurniasari et al., 2020; Rasmitadila et al., 2020). Some of the provisions above, every school has the freedom to innovate in making it happen. Like the related example of 'providing meaningful experiences for students, schools manifest in various ways. The results of interviews with representatives of guardians of students of Muhammadiyah elementary school 9 and Bani Hashim elementary school on 07-08 December 2020, it is known that the assignments given to students are different, even though the material being studied is the same. One school puts forward the skills of students and another school uses drilling questions. Private schools tend to be more flexible and varied in implementing BDR which provides meaningful learning experiences for students. This is inseparable from the pre-existing culture, where each private school has different characteristics from the others. The results of observations at Muhammadiyah elementary school 9 and Bani Hashim elementary school, Indonesia in early December 2020 note that the life skills education is closely related to the quality of the teachers, the availability of infrastructure and the learning content presented. From that basis, a learning strategy during a pandemic known as BDR was designed.

This learning strategy from home or known as BDR is a solution to the problems that exist in learning during the COVID-19 pandemic. This strategy is an effort to provide optimal educational services. At BDR, teachers are also required to prepare learning tools that allow students to learn from home (Chetty et al., 2007; Harahap \& Siregar, 2018). This situation allows teachers to change their teaching and learning strategies (Siregar, 2017). The use of appropriate teaching strategies as well as teacher behavior and attitudes in managing the teaching and learning process is needed by students during the Covid-19 pandemic, namely online learning in the home learning program (Wardani \& Ayriza, 2020; Zuo et al., 2020). The right learning strategy is used to answer the mental health needs of children, especially in the field of trauma, which has become a national public health concern and affects various other fields (Phelps \& Sperry, 2020). In addition, the strategy carried out in private elementary schools is not only to maintain the quality of learning. But also to maintain the existence of the school. Therefore, it is necessary to do more in-depth research related to the BDR strategy carried out by Muhammadiyah elementary school 9 and Bani Hashim elementary school, Malang Indonesia. This directly or indirectly means that each school has different preparations and practices in implementing different home learning strategies.

Therefore, referring to the description above, this study aims to examine the learning from home strategies during the Covid-19 pandemic in Indonesian private elementary schools. In responding to and overcoming these problems, many researchers and experts have explored and analyzed online learning. Previous research includes online learning during a pandemic (Adnan \& Anwar, 2020; Fauzi \& Khusuma, 2020) and design of an online learning platform (Kersting et al., 2018; Wang, 2019). In addition to some of the things that have been described previously, the new thing offered in this research is related to analysis in the form of descriptive exposure about learning strategies during a pandemic that has been carried out in private elementary schools. Based on the description above, the researcher hopes that this study and learning innovation will contribute to policy makers, principals, teachers and parents. From a scientific perspective, the results of this study provide a new model for online learning during the COVID-19 pandemic.

\section{METHOD}

The research method is descriptive with a qualitative research approach. Qualitative data is a source of reasonable and process human descriptions and explanations. With qualitative data, both the 
chronology and the interpretation can be clarified (Bloomberg \& Volpe, 2018). A qualitative approach was intended to understand the phenomena about what was experienced by research subjects such as their behaviour, perception, motivation, action, and so on holistically, and utilising descriptions in the form of words and language, in a special natural context and by utilising various scientific methods. Therefore, this qualitative descriptive study will describe a) Learning from Home Strategy (BDR), b) Strengths and weaknesses of each Learning from Home Strategy. The subjects of this study were 2 school principals, 2 teachers, 2 students and 2 guardians of students of Muhammadiyah 9 Elementary School Malang City and Bani Hasyim Elementary School of Malang, East Java, Indonesia. Among the research subjects, the principal of each school was the key informant in this study. The study focused on the description of learning from home strategies and the strengths and weaknesses of these strategies. Therefore, concerns related to how the implementation of school policies are described in detail in this study. As other qualitative descriptive studies, data collection in this study used open structured interviews (Creswell \& Clark, 2017). The interview process was carried out online via WA. Interviews were conducted on research subjects. In addition, data collection was also carried out by observation and documentation in December 2020. The instruments in this research is shown in Table 1.

Table 1. Research Instrument Grid

\begin{tabular}{lll}
\hline No & \multicolumn{1}{c}{ Aspect } & \multicolumn{1}{c}{ Indicators } \\
\hline 1. & Learning from home strategies & Lesson plan \\
& & Implementation \\
& & Evaluation \\
& & Infrastructure \\
& & Teacher \\
& & Teaching materials \\
$3 . \quad$ Weaknesses of the Learning from Home Strategy & Evaluation \\
& & Infrastructure \\
& & Teacher \\
& & Teaching materials \\
& & Evaluation \\
\hline
\end{tabular}

The data in this study were compiled through several techniques, namely observation, interviews, and documentation. The researchers observed the activities of students and teachers and environmental conditions (class). Researchers also conducted interviews with 2 school principals, 2 teachers, 2 students and 2 guardians. Various learning materials and products used by the teacher and the products produced by students were documented to enrich research data. Data Analysis Data analysis in this qualitative research was started when the data collection took place, and after the data collection was completed within a certain period. The data analysis implemented content analysis techniques. Activities in data analysis included data reduction which summarized, chose the main points, focused on the important things, as well as looking for themes and patterns. Moreover, data display organized the data, arranged in a relationship pattern, so that it would be more easily understood. Finally, the conclusion drawing/verification was to conclude the data originally compiled as temporary and would change if no substantial evidence was found that supports the next stage of data collection. If the conclusions expressed at an early stage were supported by valid and consistent evidence by the time the researchers returned to the field to collect data, then the conclusions put forward were assumed as credible conclusions.

\section{RESULT AND DISCUSSION}

\section{Result}

Understand that the presence of the teacher cannot be replaced, but teachers need to be supported to be able to disseminate knowledge in a more interactive and fun for learning, it is necessary to be implemented the right strategy. This study aims to analyze learning from home strategies, the strengths and weaknesses of each home learning strategy. This learning from home strategy is part of the learning policy in the context of handling the Covid-19 outbreak carried out by Muhammadiyah 9 Elementary School Malang City and Bani Hasyim Elementary School of Malang, East Java, Indonesia. As data collection conducted in December 2020, it is known that the two schools have carried out learning in accordance with Circular (SE) Number 4 of 2020 dated March 24, 2020, namely Learning from Home (Arifa, 2020). The research that was carried out was described in accordance with the results of the six 
steps of data analysis which began with the following coding stages. The coding of research results is shown in Table 2.

Table 2. Coding of research results

\begin{tabular}{|c|c|c|c|}
\hline No & Aspect & Subject & Coding \\
\hline 1. & $\begin{array}{l}\text { Learning from home } \\
\text { strategies }\end{array}$ & $\begin{array}{l}\text { Principals, Students' } \\
\text { Guardian, Teacher }\end{array}$ & $\begin{array}{l}\text { The three schools apply } \\
\text { synchronous and asynchronous } \\
\text { with different implementation } \\
\text { strategies }\end{array}$ \\
\hline 2. & $\begin{array}{l}\text { Strengths of the } \\
\text { Learning from Home } \\
\text { Strategy }\end{array}$ & $\begin{array}{l}\text { Principals, Students' } \\
\text { Guardian, Teacher, Students }\end{array}$ & $\begin{array}{ll}\text { a. } & \text { For students } \\
\text { b. For teacher } \\
\text { c. For students' guardian } \\
\text { d. For the principals }\end{array}$ \\
\hline 3. & $\begin{array}{l}\text { Weaknesses of the } \\
\text { Learning from Home } \\
\text { Strategy }\end{array}$ & $\begin{array}{l}\text { Principals, Students' } \\
\text { Guardian, Teacher, Students }\end{array}$ & $\begin{array}{ll}\text { a. For students } \\
\text { b. For teacher } \\
\text { c. For students' guardian } \\
\text { d. For the principals }\end{array}$ \\
\hline
\end{tabular}

Coding in table 2 is to summarize, highlight the message, capture the essence of a portion of data, whether it is language -based data or visual data. As for the explanation of learning from home as follows. In general, the results of the data analysis in the second to sixth steps describe the home learning strategy as well as the strengths and weaknesses of each strategy. Based on the results of interviews, observations and documentation to the principal as the key informant as well as to the teachers, guardians of students and students of these 2 schools during December 2020, it is known that the data on learning strategies from home as well as the strengths and weaknesses of each strategy.

Muhammadiyah 9 Elementary School Malang City implements the learning strategy from home as part of the policy to deal with the Covid-19 pandemic through learning from home in a synchronous and asynchronous way. The strategy is carried out by optimizing social media that takes place every day. Social media is used to send learning package, media, teaching materials, worksheets and student evaluation links (Salamah, 2017). In addition, social media is used as a medium for collecting student work results every day. Based on the results of interviews with grade 6 teachers of Muhammadiyah 9 Elementary School Malang City on December 10, 2020, most of the learning process from home through online learning is currently still using the WhatsApp group facility on smart phone devices. The teacher sends a package of materials, media, teaching materials, worksheets and student evaluation links to students via the WhatsApp group, both through the parents' group and their respective class groups. For example, on Monday, there is thematic learning, SBdP (Cultural Arts and Crafts) and Islamic studies. Then the materials and assignments were sent in the morning (06.00-07.00) according to the schedule. The teacher sends thematic learning materials and assignments according to the schedule when the thematic learning schedule takes place.

Meanwhile, for the sending of learning materials to the lower classes, it is carried out in detail every day and written in a simple manner directly referring to the pages that must be read, practiced or completed. Especially for $1^{\text {st }}$ and $2^{\text {nd }}$ grades, the class teacher has prepared a module for learning which contains learning material, student worksheets. During the completion of the assignment, if students feel there is a lack of understanding or learning difficulties, students can ask the Teacher anytime by WhatsApp that has been scheduled by the Teacher. According to the $6^{\text {th }}$ grades teacher as one of the research subjects interviewed on December 11, 2020, it was stated that the difficulty levels of students were different in several factors, one of which is parental assistance to students. If students have a career parents, students and parents need more assistance from the teacher both for completing assignments and in understanding the material. The teacher has additional duties, not only to provide understanding to students, but also provides understanding for parents. However, the difference is that for parents, there is more understanding regarding the delivery of daily tasks. On the other hand, learning from home has additional impact on parents, namely stimulating closeness between family members. According to the parents, the tasks given by the Teacher involve more family members. Therefore, during learning from home, students do not get bored and increase the closeness between other family members. In addition, learning from home is a stimulus for students to care more about the environment.

The use of the surrounding environment is also part of a variety of learning from home packages. Of course, the condition of students is very dependent on parental assistance. If many students are left by their parents to complete assignments independently, the daily material package is considered as a burden by students. At this point, the teacher provides a lot of assistance through synchronous activities 
using social media as the results of observations at synchronous times. Therefore, the maximum collection of assignments at 19.00 according to the parents is very humane for all students with various conditions. This means that after work, each parent still has time to assist the children in learning and completing assignments. Meanwhile, the time in one day when students do not complete the assignment is used for character habituation activities or memorizing letters in the Holy Quran. Especially for the habituation of character and memorization of the letters of the Holy Quran according to the grade level. This is because as an Islamic school, this elementary school under the guidance of the University of Muhammadiyah Malang has implemented memorizing targets for short letters of the Holy Quran to all students. Therefore, learning from home is carried out synchronously and asynchronously. But the strategy is done by providing learning packages every day. Synchronous activities are carried out for assistance for students according to the agreement of the teacher, student and students' guardian.

Based on the description of the results above, learning from home has become a new habit that has its own strengths and weaknesses. However, both the principal, teachers and student guardians have the same answer that face-to-face learning activities are better for student development, both academic and non-academic as well as students' psychological development. On the other hand, students also prefer face-to-face learning because they can interact with other students. In implementing learning from home, Bani Hasyim Elementary School of Malang implements learning strategies using applications. Synchronous and asynchronous learning activities using the PANDAWA application. Pandawa is an acronym of "Panduan Pembelajaran Daring Siswa". According to the Principal, this application was developed by the teacher in the last 6 months to support learning from home strategies. Based on the results of interviews with the Principal of Bani Hasyim Elementary School of Malang on December 10, 2020 regarding the application of the PANDAWA application, it is known that this application really supports learning from home activities. Students must enter the application every day to find out the learning videos, teaching materials and assignments given by the teacher, which are on the learning video link in the application. All grade levels have been facilitated by the PANDAWA application. The person who in charge of the application is each teacher according to the class level. Teachers develop materials, teaching materials, worksheets and assessment questions. Therefore, with use this application then a teacher or employees don't need paper anymore to print the quiz or questionnaire. Time what it needs will also be more efficient in handing out, gathering back and analyze the results of the quizzes and questionnaires. Thus, this application is perfect used to gather opinions a group of distant and difficult people collected, manage event registration or school via internet pages, collect data, make quizzes sudden, and more. Furthermore, the IT team helped to enter the PANDAWA application.

According to the $4^{\text {th }}$ grade students at SD Bani Hasyim, this application directs students to learn face to face in class as before, but done it from home. This is because learning activities before learning from home also use a lot of learning videos. Therefore, when studying from home using applications, students are not awkward. Students receive directions for learning activities by the application every day, then proceed with carrying out activities according to the directions in the application. Students are freely to chat with the teacher either using the application or using social media. Thus, if there are misconceptions or difficulties in their learning, they can be handled properly. This is what Bani Hasyim Elementary School of Malang later called synchronous activity.

The PANDAWA application requires teachers to be creative in presenting learning techniques. This is what makes the parents believe that learning from home does not reduce the quality of learning. Although on the other hand learning from home requires a lot of data packages because it has to provide guidance on the stages of learning. The results of the assessment of student work that have been collected can also be seen in this PANDAWA application. Through the same application, students can also interact with other friends. Therefore, the existence of this applications is very helpful when studying from home. Nevertheless, both the Principal, Students, Teachers and student guardians have high hopes that face-toface learning can be carried out as soon as possible. This is because with face to face learning, students can interact directly and support student development where the age of the students is at the stage of playing development.

Based on the results of the analysis regarding the learning from home strategy, it is known that the strengths and weaknesses of the learning from home strategy in these two private schools in Malang. The strengths and weaknesses are described for students, teachers, schools and student guardians as described below. The advantages of learning from home strategies are a) flexibility in the learning time, b) increasing student interaction with parents, teachers and teaching materials, c) students are more independent and responsible for their duties, d) students' communication and questioning skills are improved, e) mastering IT and social media for students and parents, f) the use of social media and applications can minimalize misconceptions and student learning difficulties, g) increasing the creativity of teachers in preparing resources, media and teaching materials in learning, h) quality assurance of 
learning can be done properly, i) schools have the opportunity to identify improvements in human resources and facilities and infrastructure, j) opening opportunities or job vacancies for IT experts, k) using of applications learning can minimize paper usage, l) the use of applications can minimize the time and effort for conducting assessments.

Then the weaknesses of online learning strategies are a) there may be differences in understanding of the material and misconceptions that cannot be resolved immediately, b) when learning is sent in the form of a learning package, there is a time delay when there are misconceptions or learning difficulties, c) both teachers and students can experience problems if they do not have access to a strong internet network, d) requires the presence of teachers and students to be present at the same time, so that if there are obstacles to the presence of both, it will make scheduling difficulties, e) not able to detect active and inactive students, f) synchronous activities consume a large amount of internet quota, but when receiving quota assistance from the government or schools it becomes lighter, g) requires supporting infrastructure to prepare learning packages and learning applications, h) parents' time is used up for children's zoom meeting activities. On the other hand, parents also have to work. So there needs to be another solution for students whose parents work, i) students are vulnerable to opening other content. For example, games or negative content.

\section{Discussion}

Learning from home using online learning, forcing schools directly or indirectly to follow the online learning flow so that learning can be held (Kurniasari et al., 2020; Rasmitadila et al., 2020). Full online learning is carried out from 1st to 6th grade in elementary school, in accordance with Circular (SE) Number 4 of 2020 dated March 24, 2020, namely Learning from Home (Arifa, 2020; Barker et al., 2020). Based on the results of interviews with the principal, teachers, students and guardians of students in midDecember 2020, information was obtained that the school had provided online assignments since the Covid-19 pandemic in early March 2020. The platforms used by each school is vary, including PANDAWA application that is managed by schools, Instagram, email and all schools that support the application of learning from home. Therefore, when learning from home occurs, the learning has been able to run well and even developments have been carried out in the learning process in the form of applications. Thus, it becomes the positive value of learning from home, where schools carry out learning-oriented in the 21st century (Costa et al., 2021). These two schools are the leading private schools in the City of Education. This means that in terms of human resources and facilities and infrastructure, both educators and students are ready (Murata et al., 2012). Although many are forced to be prepared for learning which is usually carried out face-to-face, it has turned into an online learning system. For schools that are accustomed to using technological devices in teaching and learning activities, of course this is a trigger for all elements of the school to develop according to technological advances (Plass \& Kaplan, 2016).

However, as something new, learning from home using online platform, students are very dependent on teachers (Costa et al., 2021). Technological complexity has not been able to encourage fluency in learning without good internet access (Leonard, 2016). In addition, parental assistance is one of the keys to successful learning from home (Jasinski, 2012; Sanner \& Neece, 2018). The habit of using technology for the community and parental assistance are parts of the success of learning from home (Jasinski, 2012; Mellon \& Moutavelis, 2011). During the learning from home activities, Teacher has also additional assignments. Not only helping students to learn, but also teaching parents to be able to access the technology (Wilder, 2014). Therefore, the school took various policies in addressing learning from home strategies during Covid-19. This includes habits that are carried out in the family environment (Sanner \& Neece, 2018). The use of applications and social media in the learning process that supports the paper saving program as form of environmental care (Batubara, 2016).

The platforms used by teachers in the implementation of learning from home are expected not only to focus on academic or cognitive achievements, but also emphasize the development of life skills and character, such as independent, disciplined and responsible characters (Kautsar \& Edi, 2017; Völker, 2018). This is one of the keys to be meaningful and enjoyable learning for students (Ansari et al., 2016; Setyaningrum, 2013; Wardani \& Ayriza, 2020). At this time, Ki Hajar Dewantara's statement fits perfectly, "make every house a school and make everyone a teacher". Therefore, the jargon conveyed by the Ministry of Education and Culture on the commemoration of National Education Day, namely "Learning from Covid-19" has a lot of meaning in civilizing quality and being able to develop the quality of learning that has been implemented by schools (Völker, 2018; Zuo et al., 2020). The period of handling the Covid19 pandemic has become a medium for increasing the human resource of teachers directly or indirectly (Harpaz, 2014; Leonard, 2016). The success of learning from home by implementing its various strategies is one of the benchmarks for the quality of education in this country (Hafermalz \& Riemer, 2020). In the end, it will appear directly or indirectly, that the school is ready to welcome all changes or not. Especially 
in the face of changing times and changes in generations at this time and in the future (Plass \& Kaplan, 2016). The success of learning from home by implementing various strategies is one of the standards for the quality of education in this country (Arifa, 2020). In the end, it will appear directly or indirectly, that the school who is ready to welcome all changes and who are not. Especially changes in the face of changing times and changing generations in the present and future (Wilder, 2014). Based on the results and discussion, this research is limited to private elementary schools in Indonesia. This research also provides benefits to teachers, principals and parents in designing learning during the pandemic. This strategy can be used as an alternative to learning with an implementation guide. This makes it easier for stakeholders to implement learning.

\section{CONCLUSION}

It is known that learning from home strategies are Synchronous and Asynchronous Using Social Media and Synchronous and Asynchronous Using Learning Applications. The strategies carried out are a) learning packages containing teaching material, learning media, teaching materials, student worksheets and evaluation questions using social media, b) using the PANDAWA learning application which contains school content (vision, mission, school march) and learning videos which contain learning packages every day. Asynchronous activities are aimed at providing assistance to students, minimizing misconceptions and student learning difficulties. Based on the research results, the power of home learning strategy consists of twelve analyzes. While the weaknesses of online learning strategies based on the findings consist of nine weaknesses. For example, games or negative content. Furthermore, there are several recommendations that need to be considered, and further considered, especially by advanced researchers. The recommendations are related to a) the preparation of an optimal lesson plan, b) this strategy can be implemented with material content that is in accordance with thematic learning, c) it is necessary to design a systematic learning evaluation, d) a learning guide book from home can be accessed online, and e) research development is needed for public elementary schools.

\section{REFERENCES}

Adnan, M., \& Anwar, K. (2020). Online Learning amid the COVID-19 Pandemic: Students' Perspectives. Online Submission, 2(1), 45-51. https://eric.ed.gov/?id=ED606496.

Alrefaie, Z., Hassanien, M., \& Al-Hayani, A. (2020). Monitoring Online Learning During COVID-19 Pandemic; Suggested Online Learning Portfolio (COVID-19 OLP). MedEdPublish, 9(1), 1-4. https://doi.org/10.15694/mep.2020.000110.1.

Ansari, N. J. R., Dhongade, R. K., Lad, P. S., Borade, A., Suvarna, Y. G., Yadav, V., Mehetre, A., \& Kulkarni, R. (2016). Study of Parental Perceptions on Health \& Social Needs of Children with NeuroDevelopmental Disability and It's Impact on the Family. Journal of Clinical and Diagnostic Research, 10(12), SC16-SC20. https://doi.org/10.7860/JCDR/2016/22538.9039.

Arifa, F. N. (2020). Tantangan Pelaksanaan Kebijakan Belajar dari Rumah dalam Masa Darurat Covid-19. Info Singkat; Kajian Singkat Terhadap Isu Aktual Dan Strategis, 12(7/I), 6. https://berkas.dpr.go.id/sipinter/files/sipinter-630-989-20200707165734.pdf.

Barker, R. O., Hanratty, B., Kingston, A., Ramsay, S. E., \& Matthews, F. E. (2020). Changes in Health and Functioning of Care Home Residents over Two Decades: What Can We Learn from PopulationBased Studies? Age and Ageing, 44. https://doi.org/10.1093/ageing/afaa227.

Batubara, H. H. (2016). Penggunaan Google Form sebagai Alat Penilaian Kinerja Dosen di Prodi PGMI Uniska Muhammad Arsyad Al Banjari. Al-Bidayah: Jurnal Pendidikan Dasar Islam, 8(1), 40-50. https://doi.org/10.14421/al-bidayah.v8i1.91.

Bloomberg, L. D., \& Volpe, M. (2018). Completing Your Qualitative Dissertation: A Road Map from Beginning to End (4th ed.). SAGE Publications, Inc.

Bostan, S., Erdem, R., Öztürk, Y. E., Kılıç, T., \& Yılmaz, A. (2020). The Effect of Covid-19 Pandemic on the Turkish Society. Electronic Journal of General Medicine, 17(6). https://doi.org/10.29333/ejgm/7944.

Chetty, M., Sung, J. Y., \& Grinter, R. E. (2007). How Smart Homes Learn: The Evolution of the Networked Home and Household. Lecture Notes in Computer Science (Including Subseries Lecture Notes in Artificial Intelligence and Lecture Notes in Bioinformatics), 127-144. https://doi.org/10.1007/978-3-540-74853-3_8.

Chowell, G., \& Mizumoto, K. (2020). The Covid-19 Pandemic in the USA: What Might We Expect? The Lancet, 395, 1093-1094. https://doi.org/10.1016/S0140-6736(20)30743-1.

Costa, P., Castaño-Muñoz, J., \& Kampylis, P. (2021). Capturing Schools' Digital Capacity: Psychometric Analyses of the SELFIE Self-Reflection Tool. Computers and Education, 162(November 2020). 
https://doi.org/10.1016/j.compedu.2020.104080.

Creswell, J. W., \& Clark, V. L. P. (2017). Designing and Conducting Mixed Methods Research. SAGE Publications Inc.

Fauzi, I., \& Khusuma, I. H. S. (2020). Teachers' Elementary School in Online Learning of COVID-19 Pandemic Conditions. Jurnal Iqra': Kajian Ilmu Pendidikan, 5(1), 58-70. https://journal.iaimnumetrolampung.ac.id/index.php/ji/article/view/914.

Hafermalz, E., \& Riemer, K. (2020). Productive and Connected while Working from Home: What ClientFacing Remote Workers Can Learn from Telenurses about Belonging through Technology. European Journal of Information Systems, 00(00), 1-11. https: //doi.org/10.1080/0960085X.2020.1841572.

Harahap, M., \& Siregar, L. M. (2018). Mengembangkan Sumber dan Media Pembelajaran. Educational, 10(January). https://doi.org/10.13140/RG.2.2.19282.86721.

Harpaz, Y. (2014). Teaching and Learning in a Community of Thinking: The Third Model. Teaching and Learning in a Community of Thinking: The Third Model. https://doi.org/10.1007/978-94-0076940-3.

Jasinski, M.-A. (2012). Helping Children to Learn at Home: A Family Project to Support Young EnglishLanguage Learners. TESL Canada Journal, 29, 224. https://doi.org/10.18806/tesl.v29i0.1119.

Kautsar, A., \& Edi, J. (2017). Pendidikan Karakter Religius, Disiplin, dan Bakat melalui Penigkatkan Kualitas Sarana Prasarana Sekolah. JMKSP (Jurnal Manajemen, Kepemimpinan, Dan Supervisi Pendidikan), 2(2), 259-278. https://doi.org/10.31851/jmksp.v2i2.1475.

Kersting, M., Henriksen, E. K., Bøe, M. V., \& Angell, C. (2018). General Relativity In Upper Secondary School: Design and Evaluation of an Online Learning Environment Using the Model of Educational Reconstruction. Physical Review Physics Education Research, 14(1). https://doi.org/10.1103/PhysRevPhysEducRes.14.010130.

Kurniasari, A., Pribowo, F. S. P., \& Putra, D. A. (2020). Analisis Efektivitas Pelaksanaan Belajar dari Rumah (BDR) Selama Pandemi Covid-19. Jurnal Review Pendidikan Dasar: Jurnal Kajian Pendidikan dan Hasil Penelitian, 6(3), 246-253. https://doi.org/10.26740/jrpd.v6n3.p246-253.

Leonard, L. (2016). Kompetensi Tenaga Pendidik di Indonesia: Analisis Dampak Rendahnya Kualitas SDM Guru dan Solusi Perbaikannya. Formatif: Jurnal Ilmiah Pendidikan MIPA, 5(3), 192-201. https://doi.org/10.30998/formatif.v5i3.643.

Masonbrink, A. R., \& Hurley, E. (2020). Advocating for Children During the COVID-19 School Closures. Pediatrics, 146(3). https://doi.org/10.1542/PEDS.2020-1440.

Mellon, R. C., \& Moutavelis, A. G. (2011). Parental Educational Practices in Relation to Children's Anxiety Disorder-Related Behavior. Journal of Anxiety Disorders, 25(6), 829-834. https://doi.org/10.1016/j.janxdis.2011.04.003.

Murata, A., Bofferding, L., Pothen, B. E., Taylor, M. W., \& Wischnia, S. (2012). Making Connections among Student Learning, Content, and Teaching: Teacher Talk Paths in Elementary Mathematics Lesson Study. Journal for Research in Mathematics Education, 43(5), 616-650. https://doi.org/10.5951/jresematheduc.43.5.0616.

Phelps, C., \& Sperry, L. L. (2020). Children and the Covid-19 Pandemic. Psychological Trauma: Theory, Research, Practice, and Policy, 12, 73-75. https://doi.org/10.1037/tra0000861.

Plass, J. L., \& Kaplan, U. (2016). Emotional Design in Digital Media for Learning. Emotions, Technology, Design, and Learning.

Rasmitadila, Aliyyah, R. R., Rachmadtullah, R., Samsudin, A., Syaodih, E., Nurtanto, M., \& Tambunan, A. R. S. (2020). The Perceptions of Primary School Teachers of Online Learning During the Covid-19 Pandemic Period: A Case Study in Indonesia. Journal of Ethnic and Cultural Studies, 7(2), 90-109. https: //doi.org/10.29333/ejecs/388.

Salamah, U. (2017). Model Pembelajaran Tematik Pendidikan Agama Islam di Sekolah Dasar. Jurnal Pendidikan Agama Islam, 11(1), 119-132. https://doi.org/10.14421/jpai.2014.111-08.

Sanner, C. M., \& Neece, C. L. (2018). Parental Distress and Child Behavior Problems: Parenting Behaviors as Mediators. Journal of Child and Family Studies, 27(2), 591-601. https://doi.org/10.1007/s10826-017-0884-4.

Setyaningrum, R. W. (2013). Model Pembelajaran Pendidikan Karakter pada Pembelajaran Tematik di SD Muhammadiyah 9 Kota Malang. Jurnal Pemikiran dan Pengembangan Sekolah Dasar (JP2SD), 1(1), 46. https://doi.org/10.22219/jp2sd.v1i1.1529.

Siregar, N. R. (2017). Persepsi Siswa Pada Pelajaran Matematika: Studi Pendahuluan pada Siswa yang Menyenangi Game. Prosiding Temu Ilmiah X Ikatan Psikologi Perkembangan Indonesia, 224-232. http://jurnal.unissula.ac.id/index.php/ippi/article/view/2193.

Spinelli, A., \& Pellino, G. (2020). Covid-19 Pandemic: Perspectives on an Unfolding Crisis. British Journal of 
Surgery, 107(7), 785-787. https://doi.org/10.1002/bjs.11627.

Völker, K. (2018). Nasr Hamid Abu Zayd's Philosophy on Islam and Education. In International Handbook of Philosophy of Education (pp. 17-28). Springer.

Wang, Q. (2019). Developing a Technology-Supported Learning Model for Elementary Education Level. Elementary School Forum (Mimbar Sekolah Dasar), 6(1), 141-146. https: //doi.org/10.1109/ICAIE.2010.5641449.

Wardani, A., \& Ayriza, Y. (2020). Analisis Kendala Orang Tua dalam Mendampingi Anak Belajar di Rumah Pada Masa Pandemi Covid-19. Jurnal Obsesi: Jurnal Pendidikan Anak Usia Dini, 5(1), 772. https://doi.org/10.31004/obsesi.v5i1.705.

Wilder, S. (2014). Effects of Parental Involvement on Academic Achievement: A Meta-Synthesis. Educational Review, 66(3), 377-397. https://doi.org/10.1080/00131911.2013.780009.

Zuo, L., Dillman, D., \& Miller Juvé, A. (2020). Learning at Home During Covid-19: A Multi-Institutional Virtual Learning Collaboration. Medical Education, 54(7), 664-665. https://doi.org/10.1111/medu.14194. 